\title{
Rectal Biopsy
}

National Cancer Institute

\section{Source}

National Cancer Institute. Rectal Biopsy. NCI Thesaurus. Code C51693.

Removal of rectal tissue, for microscopic examination. 